\begin{tabular}{lllllllllllll}
$\mathbf{A}$ & $\mathbf{D}$ & $\mathbf{M}$ & $\mathbf{I}$ & $\mathbf{N}$ & $\mathbf{I}$ & $\mathbf{S}$ & $\mathbf{T}$ & $\mathbf{R}$ & $\mathbf{A}$ & $\mathbf{C}$ & $\mathbf{J}$ & $\mathbf{A}$ \\
\hline
\end{tabular}

ROCZNIKI NAUK PRAWNYCH

Tom XXIX, numer $4-2019$

DOI: http://dx.doi.org/10.18290/rnp.2019.29.4-13

PAWEŁ GACEK

\title{
ZWOLNIENIE ZE SŁUŻBY W POLICJI NA PODSTAWIE ART. 41 UST. 2 PKT 5 USTAWY O POLICJI A PRAWO POLICJANTA DO NAGRODY ROCZNEJ
}

\begin{abstract}
WSTĘP
Służba w Policji jest szczególnego rodzaju służbą publiczną. Misją tej formacji jest bowiem ochrona bezpieczeństwa ludzi oraz utrzymywanie bezpieczeństwa i porządku publicznego ${ }^{2}$ (art. 1 ust. 1 ustawy z dnia 6 kwietnia 1990 r. o Policji3). Powołany przepis tej ustawy wskazuje ponadto, iż Policja jest organizacją służącą społeczeństwu. Oznacza to, że jej zadania muszą koncentrować się na zapewnieniu i ochronie bezpieczeństwa wszystkim członkom tworzącym to społeczeństwo ${ }^{4}$. Służebna rola Policji w stosunku do społeczeństwa jest na tyle istotna, że została zamieszczona expressis verbis w przepisie art. 1 ust. 1 ustawy o Policji ${ }^{5}$, który co należy zaznaczyć, określa zasadniczy obszar działań, do podejmowania których

Dr PAwet GACEK - doktor nauk prawnych; e-mail: p.gacek@wp.pl; https://orcid.org/00000001-6365-3146

${ }^{1}$ Szerzej na ten temat: M. WieCzOREK, Charakter prawny stosunków stużbowych funkcjonariuszy stużb mundurowych, Toruń: Wydawnictwo Adam Marszałek 2017, s. 19 n.

${ }^{2}$ „Celem tej formacji jest służenie społeczeństwu poprzez ochronę bezpieczeństwa ludzi oraz utrzymywanie bezpieczeństwa i porządku publicznego”, B. OPALIŃSKI, M. RogalSKI, P. SzuSTAKIEwicz, Uwagi do art. 1, [w:] Ustawa o Policji. Komentarz, Warszawa 2015, Legalis/el., a także B. OpalıŃski, P. Szustakiewicz, Policja studium administracyjnoprawne, Warszawa: Oficyna Wydawnicza Uczelnia Łazarskiego 2013, s. 26.

${ }^{3}$ Ustawa z dnia 6 kwietnia 1990 r. o Policji, Dz. U. z 2020 r., poz. 360 z późn. zm.

${ }^{4}$ S. Pieprzny, Policja. Organizacja i funkcjonowanie, Warszawa: Wolters Kluwer Polska sp. Z o.o. 2011, s. 28.

${ }^{5}$ „Choć w art. 1 ust. 1 ustawy o Policji nie ujęto wprost sformułowania, że Policja jest instytucją zaufania publicznego, to w istocie rzeczy, treść tego przepisu na to wskazuje. Na zaufaniu społecznym opiera się zatem m.in. status Policji, a charakter zadań Policji, z oczywistych względów wymaga, by cieszyła się ona autorytetem i zaufaniem w społeczeństwie", wyrok Naczelnego Sądu Administracyjnego [dalej: NSA] z dnia 16 grudnia 2010 r., sygn. akt I OSK 962/10, Legalis nr 307954.
\end{abstract}


zobligowana jest ta organizacja. Dodać także należy, iż Policja została utworzona na wzór wojskowy. Jej militarny (paramilitarny) charakter podkreśla ta część powołanego wyżej przepisu ustawy o Policji, który wskazuje, że „tworzy się Policję jako umundurowaną i uzbrojoną formację"6. Poszczególne zadania Policji wymienia natomiast art. 1 ust. 2 ustawy o Policji. Nie tworzy on katalogu zamkniętego ${ }^{7}$. Stanowi raczej przykładową egzemplifikację obszarów (sfer) działania, w których Policja zobligowana jest podejmować swoją aktywność, aby mogła realizować swoje zadania ${ }^{8}$.

Rozwój różnych sfer życia społecznego rodzi rożnego rodzaju zagrożenia. Tam bowiem, gdzie aktywność przejawia człowiek mogą pojawiać się różnego rodzaju niekorzystne zjawiska, w tym w szczególności zagrożenia związane z przestępczością oraz innego typu patologiami. Z kolei na Policji spoczywa, w największym stopniu, obowiązek zapewnienia bezpieczeństwa i porządku publicznego. Inne formacje (służby, inspekcje i straże) współuczestniczą jedynie w wykonywaniu zadań z tego zakresu. Ich udział ma jedynie charakter uzupełniający ${ }^{9}$. Policja jest

6 „Policja stanowi również formację umundurowaną. Umundurowanie ma na celu wyróżnienie policjanta będącego w służbie, a także odróżnienie go od funkcjonariuszy innych służb”, Z. GĄDZIK, Przepisy ogólne. Istota funkcjonowania Policji, podstawowe zadania Policji, [w:] Ł. Czebotar, Z. GĄDzIK, A. Łyżwa [i in.], Komentarz. Ustawa o Policji, Warszawa: Wolter Kluwer S.A. 2015, s. 30.

7 „Przepis art. 1 ust. 2 wymienia podstawowe zadania Policji. Nie wymienia więc ich w sposób enumeratywny, ale jedynie wskazuje na zadania podstawowe”, OpALIŃSKI, RoGalSKI, SzUSTAKIEwiCz, Uwagi do art. 1; w tym samym tonie GĄDZIK, Przepisy ogólne, s. 28; Z. PiąTEK, R. Socha, P. Wars, Charakterystyka Policji, [w:] Współczesny wymiar funkcjonowania Policji, red. B. Wiśniewski, Z. Piątek, Warszawa: Akademia Obrony Narodowej 2009, s. 29 n.; Opaliński, Szustakiewicz, Policja, s. 27 n., a także S. Pieprzny, który wskazuje na brak możliwości dokładnego określenia granic tych zadań (Pieprzny, Policja, s. 28). „W art. 1 ust. 2 ustawy o Policji ustawodawca wymienił zadania Policji o podstawowym charakterze. Takie wskazanie należy rozumieć jako katalog o otwartym charakterze, bowiem termin „podstawowe” oznacza zadania pierwszoplanowe i mające charakter pryncypialny”, E. Żywucka-KozŁowska, Policja. Zagadnienia wybrane, Szczecin: Szczecińska Szkoła Wyższa Collegium Balticum 2014, s. 14.

8 „Katalog ten ma charakter ogólny - rozszerzenie zadań przysługujących Policji oraz ich konkretyzacja zawarte zostały w dalszych przepisach ustawy o Policji, ustawach szczególnych oraz właściwych dla nich aktach wykonawczych, a także na gruncie aktów normatywnych o charakterze wewnętrznym - zarządzeń, regulaminów, decyzji, wytycznych i porozumień z organami administracji publicznej i innymi podmiotami”, GĄDZIK, Przepisy ogólne, s. 31, a także Z. LeoŃski, Materialne prawo administracyjne, Warszawa: C.H. Beck 2000, s. 174; E. UrA, E. Ura, Prawo administracyjne, Warszawa: Wydawnictwo Prawnicze LexisNexis 2004, s. 388; E. Ura, Administracja bezpieczeństwa i porzadku publicznego, [w:] Prawo administracyjne, red. E. Ura, Rzeszów: Wydawnictwo Oświatowe FOSZE 1997, s. 361.

9 „Obok organów Policji, przewidziane ustawą o Policji cele i zadnia realizują - w ograniczonym zakresie - również inne organy administracji publicznej", W. MaCıEJKo, Osobowe prawo administracyjne, Warszawa: C.H. Beck 2008, s. 149; Tenże, M. Rouewski, A. SuŁawko-Karetko, Prawo administracyjne. Zarys wykładu części szczególnej, Warszawa: C.H. Beck 2011, s. 134. 
największą organizacją, tj. najbardziej liczną, wobec czego zakres zadań przekazanych jej do realizacji przez ustawodawcę jest największy. Stąd też, zajmuje ona szczególne miejsce w systemie organów administracji publicznej odpowiedzialnych za zapewnienie bezpieczeństwa i porządku publicznego. Wynika to głównie z tego, że zajmuje się ona niemal wszystkimi lub wręcz wszystkimi zagadnieniami w tej sferze $^{10}$, a także nadzoruje i koordynuje działania innych służb, inspekcji i straży, które uczestniczą w ograniczonym zakresie w wykonywaniu tych zdań.

Policja musi być gotowa, a także przystosowana organizacyjnie, do podejmowania działań zapobiegających rozszerzaniu się wymienionych wyżej zjawisk, a także eliminowania skutków ich wystąpienia. Jak każda formacja, Policja działa za pośrednictwem swoich członków, tj. funkcjonariuszy, którzy wykonując powierzone im zadania, w szerszym aspekcie realizują ustawowe zadania Policji. Suma działań podjętych przez poszczególnych funkcjonariuszy jest bowiem świadectwem tego, że Policja zmierza do urzeczywistnienia, tj. wypełnienia nałożonych na nią zadań. Zatem wyłącznie dzięki poszczególnym działaniom podejmowanym przez funkcjonariuszy możliwa jest realizacja zadań przewidzianych dla tej formacji.

$\mathrm{Z}$ uwagi na fakt, że członkowie tej organizacji są kluczowym elementem, dzięki któremu możliwe staje się wykonywanie (realizacja) ustawowych zadań Policji, konieczne stało się uregulowanie statusu członka tej formacji jako cząstki składowej struktury zhierarchizowanej i zmilitaryzowanej. Należy bowiem podkreślić, że więź prawna istniejąca pomiędzy osobą fizyczną (funkcjonariuszem) a podmiotem zatrudniającym (przełożonym właściwym w sprawach osobowych) stanowi źródło wzajemnych praw i obowiązków pomiędzy tymi podmiotami. Ową więzią prawną jest stosunek służbowy, który ma charakter wyłącznie administracyjnoprawny ${ }^{11}$.

${ }^{10}$ J. Doвкоwsкi, Administracja bezpieczeństwa i porzadku publicznego, [w:] Wybrane zagadnienia administracyjnego prawa materialnego, red. W. Bednarek, Olsztyn: Wydawnictwo Uniwersytetu Warmińsko-Mazurskiego 2000, s. 139. Policja jest bowiem podstawową formacją, której zadaniem jest zapewnienie bezpieczeństwa i porządku publicznego, E. Olejniczak-Szalowska, Pojęcie bezpieczeństwa i porzadku publicznego. Policja administracyjna, [w:] Prawo administracyjne materialne, red. Z. Duniewska, B. Jaworska-Dębska, M. Stahl, Warszawa: Wolters Kluwer S.A. 2014, s. 662 .

${ }^{11}$ P. GACEK, Nawiązanie stosunku stużbowego z funkcjonariuszem Policji, „Administracja Teoria Dydaktyka Praktyka” 23 (2011), nr 2, s. 76 n.; Tenże, Odwołanie od rozkazu personalnego, „Przegląd Policyjny" 123 (2016), nr 3, s. 80; M. TAniewska, Stosunek stużbowy funkcjonariuszy Policji, Urzędu Ochrony Państwa i Straży Granicznej, [w:] Prawo Policyjne. Komentarz, red. S. Sagan, Katowice: Biuro Wydawnictw Prawniczych „POLBOD” 1992, s. 69; J. KACPRZAK, Stosunki stużbowe w formacjach zmilitaryzowanych - charakter prawny, ochrona sądowa, „Przegląd Policyjny” 33 (1994), nr 1, s. 97; M. Liwo, Status stużb mundurowych i funkcjonariuszy w nich zatrudnionych, Warszawa: LexisNexis 2013, s. 311 n.; Maciejko, Osobowe, s. 154, Tenże, Stosunek procesowy w sprawie osobowej, [w:] W. Maciejko, A. Korcz-Maciejko, Postępowanie w sprawach osobowych w Policji, Wrocław: GASKOR 2010, s. 20; Tenże, Rojewski, SuŁawko-Karetko, Postępowanie, s. 139; J. PaŚnik, Prawo 
Charakterystyczną jego cechą jest wzmożona dyspozycyjność ${ }^{12}$ co do miejsca, czasu oraz rodzaju wykonywanych czynności, podporządkowanie wobec władzy zwierzchniej, tj. podwładnego wobec przełożonego (i to nie tylko wobec bezpośredniego przełożonego, czy przełożonego właściwego w sprawach osobowych, ale także wobec innych przełożonych), a także korelująca z tym zwiększona odpowiedzialność, o charakterze dyscyplinarnym i porządkowym ${ }^{13}$.

Stosunek służbowy nie może być zatem traktowany na równi z żadną pracą najemną. Ustawodawca wyodrębniając ten stosunek prawny i nadając mu charakter administracyjnoprawny stworzył odrębną kategorię stosunku. Nie jest to zatem stosunek pracy z mianowania, o którym mowa w art. 76 ustawy z dnia 26 czerwca 1974 r. Kodeks pracy ${ }^{14}$. Jak słusznie zauważa T. Zieliński elementem odróżniającym stosunek służbowy (z mianowania) od stosunku pracy (z mianowania) jest pełna dyspozycyjność funkcjonariusza. Owa pełna dyspozycyjność jest jednocześnie kryterium odgraniczającym te dwa typy stosunków prawnych. Nasilenie pierwiastków władczych w stosunku służbowym jest tak wielkie, że reżim prawa pracy musi ustąpić reżimowi prawa administracyjnego ${ }^{15}$. Stąd też policjant nie jest pracownikiem, a przełożony nie jest pracodawcą w rozumieniu prawa pracy ${ }^{16}$, funkcjonariusz nie wykonuje pracy, a pełni służbę, za którą nie otrzymuje wynagrodzenia, tylko uposażenie.

Policjant składając oświadczenie o dobrowolnym wstąpieniu do służby, przyjmując akt mianowania i składając ślubowanie, składa jednocześnie zobowiązanie

dyscyplinarne w Polsce, Warszawa: Oficyna Prawnicza MUZA S.A. 2000, s. 167 i powołane tam orzecznictwo; Leksykon policyjny, red. W. Pływaczewski, G. Kędzierska, Szczytno: Wydawnictwo Wyższej Szkoły Policji w Szczytnie 2001, s. 304; P. Szustakiewicz, Istota stosunku stużbowego, [w:] W. Maciejko, P. Szustakiewicz, Stosunek shuzbowy w formacjach mundurowych, Legalis/el. 2016, T. Szankin, Stużba w Policji, [w:] Prawo policyjne, red. M. Czuryk, M. Karpiuk, J. Kostrubiec [i in.], Warszawa: Difin S.A. 2014, s. 200 n.; Ura, Ura, Prawo, s. 393, WieczoreK, Charakter, s. 151. Przeciwnie T. Hanausek, Ustawa o Policji. Komentarz, Kraków: Kantor Wydawniczy Zakamycze 1996, s. 72. Porównaj także ze stosunkiem służbowym funkcjonariuszy Milicji Obywatelskiej M. Zorska, Komentarze do ustaw z 31 stycznia 1950 r. o stosunku stużbowym funkcjonariuszów Milicji Obywatelskiej i z 31 stycznia 1959 r. o zaopatrzeniu emerytalnym funkcjonariuszów Milicji Obywatelskiej i ich rodzin, Warszawa: druk MSW 1960, s. 10.

${ }^{12}$ MaciejKo, Osobowe, s. 154.

13 „Jednym ze skutków nawiązania stosunku służby jest powstanie po stronie przełożonego służbowego policjanta daleko posuniętego władztwa administracyjnego - władztwa służbowego", Maciejko, Osobowe, s. 156; Tenże, Rojewski, Sulawko-Karetko, Prawo, s. 141. Z kolei obowiązek podporządkowania się policjanta (podwładnego) swojemu przełożonemu jest zabezpieczony sankcją o charakterze dyscyplinarnym.

${ }^{14}$ Ustawa z dnia 26 czerwca 1974 r. Kodeks pracy, Dz. U. z 2019 r., poz. 1040 z późn. zm.

${ }^{15}$ T. ZieLiŃsKi, Stosunek prawa pracy do prawa administracyjnego, Warszawa: Państwowe Wydawnictwo Naukowe 1977, s. 181.

${ }^{16}$ Maciejko, Osobowe, s. 154; Tenże, Rojewski, Sulawko-Karetko, Prawo, s.139. 
do dochowania obowiązków wynikających z roty złożonego przez niego ślubowania, w tym w szczególności do wiernej służby Narodowi, ochrony ustanowionego w państwie porządku prawnego, strzeżenia bezpieczeństwa państwa i jego obywateli, nawet z narażeniem życia ${ }^{17}$.

Służba w Policji rodzi zatem szereg obowiązków nieznanych innym grupom zawodowym. Stosunek służbowy musi bowiem stwarzać jak najlepsze warunki do wykonywania przez policjanta jego obowiązków. Konstrukcja tego stosunku ma także gwarantować, że zadania te będą w rzeczywistości realizowane. Pełną dyspozycyjność i podporządkowanie w służbie ma rekompensować szereg przywilejów ustanowionych dla funkcjonariuszy, których podstawą zatrudnienia jest stosunek służbowy (mianowanie). Zostały one ustanowione w ustawie o Policji. Nie sposób w ramach jednego opracowania omówić ich wszystkich. Dalsze rozważania zostaną zatem zawężone wyłącznie do przedstawienia jednej instytucji, tj. nagrody rocznej przewidzianej w art. 110 ustawy o Policji, która stanowi instrument rekompensaty za pełną dyspozycyjność funkcjonariusza w służbie, za rzeczywiste jej pełnienie, a także zagadnienia związanego z uprawnieniem do jej otrzymania w sytuacji rozwiązania stosunku służbowego, w tym w szczególności w związku ze zwolnieniem ze służby ze względu na jej ważny interes (art. 41 ust. 2 pkt 5 ustawy o Policji) ${ }^{18}$.

\section{ISTOTA NAGRODY ROCZNEJ}

$\mathrm{Z}$ treści art. 110 ust. 1 ustawy o Policji ${ }^{19}$ wynika, że policjantowi za służbę pełnioną $\mathrm{w}$ danym roku kalendarzowym przysługuje nagroda roczna w wysokości 1/12 uposażenia otrzymanego w roku kalendarzowym, za który nagroda przysługuje.

${ }^{17}$ B. Opaliński, M. Rogalski, P. Szustakiewicz, Uwagi do art. 58, [w:] Ustawa o Policji.

${ }^{18}$ Szerzej na ten temat: M. DzImIŃSKA-Mosio, Ważny interes stużby jako przesłanka zwolnienia funkcjonariusza Policji, [w:] Wspótczesne problemy prawa. Nadużycia prawa, Tom 2, red. I. Nowicka, D. Mocarska, Szczytno: Wydawnictwo Wyższej Szkoły Policji w Szczytnie 2016, s. 225 n.; P. GACeK, Zmiana stadium postępowania karnego jako podstawa do zwolnienia policjanta ze stużby w Policji ze względu na ,ważny interes stużby”, „Przegląd Policyjny” 128 (2017), nr 4, s. 70 n.; Tenże, Opinia organizacji zakładowej związku zawodowego policjantów w sprawie zwolnienia ze służby w Policji (art. 43 ust. 3 ustawy o Policji), „Policja. Kwartalnik Kadry Kierowniczej Policji” 2 (2018), s. 38 n.

${ }^{19}$ „Przepis art. 110 ustawy o Policji, określa ogólne zasady przyznawania policjantom nagród rocznych, jak też ustala przesłanki warunkujące jej obniżenie lub pozbawienie do niej prawa", wyrok Wojewódzkiego Sądu Administracyjnego w Bydgoszczy [dalej: WSA] z dnia 17 października 2018 r., sygn. akt II SA/Bd 421/18, Legalis nr 1864777; w tym samym tonie W. KoтоwsKi, Ustawa o Policji. Komentarz, Warszawa: Wolters Kluwer Polska sp. z o.o. 2008, s. 593. „Zasady przyznawania policjantowi nagrody rocznej uregulowane zostały w przepisie art. 110 ustawy o Policji”, wyrok WSA w Krakowie z dnia 23 sierpnia 2017 r., sygn. akt III SA/Kr 622/17, Legalis nr 1665440. 
Nagroda roczna przysługuje, jeżeli policjant w danym roku kalendarzowym pełnił służbę przez okres co najmniej 6 miesięcy kalendarzowych ${ }^{20}$. Okresy służby krótsze od miesiąca kalendarzowego sumuje się, przyjmując, że każde 30 dni służby stanowi pełny miesiąc kalendarzowy (art. 110 ust. 3 ustawy o Policji). Z kolei art. 110 ust. 3a ustawy o Policji wymienia okresy niewykonywania przez policjanta zadań służbowych, których nie dolicza się do okresów wskazanych w art. 110 ust. 3 ustawy o Policji, chyba, że zaistnieją przesłanki określone w art. 110 ust. $3 b^{21}$ ustawy o Policji. Co do zasady więc nagroda roczna jest uprawnieniem, które przysługuje policjantowi za służbę pełnioną w danym roku kalendarzowym ${ }^{22}$. Warunkiem koniecznym do nabycia uprawnienia do nagrody rocznej jest jednak rzeczywiste pełnienie (wykonywanie) tej służby przez okres co najmniej 6 miesięcy w roku kalendarzowym, za który nagroda ma być przyznana ${ }^{23}$. Odstępstwa od tej reguły zostały zamieszczone enumeratywnie w art. 110 ust. 4 ustawy o Policji. Wskazany katalog ma charakter zamknięty (numerus clausus). Oznacza to, że podstawowym wymogiem jest ustalenie, czy w danym roku kalendarzowym policjant pełnił służbę przez okres co najmniej 6 miesięcy (z wyłączeniem okresów wskazanych w art. 110 ust. 3a ustawy o Policji, chyba że zaistnieją przesłanki określone w art. 110 ust. $3 b$ ustawy o Policji), a także, czy nie występują sytuacje, które uprawniają policjanta do nabycia prawa do nagrody rocznej, o których mowa w art. 110 ust.

${ }^{20}$ Okres służby nie może być krótszy od 6 miesięcy kalendarzowych, wyrok NSA z dnia 17 maja 2017 r., sygn. akt I OSK 3436/15, Legalis nr 1652050; także A. ŁYżWA, M. ToKARsKI, Uposażenie i inne świadczenia pieniężne policjantów. Nagroda roczna, [w:] CzEBotaR, GĄDZIK, ŁyżwA [i in.], Komentarz, s. 590. Jest to minimalny okres pełnionej przez policjanta służby w danym roku kalendarzowym warunkujący przyznanie nagrody rocznej. Od tak ustanowionej zasady wprowadzono pewne wyjątki uzasadnione względami służbowymi i społecznymi, Koтоwski, Ustawa, s. 593.

${ }^{21}$ Umorzenie postępowania, o którym mowa w art. 110 ust. 3b ustawy o Policji nie dotyczy warunkowego umorzenia postępowania karnego lub postępowania w sprawie o przestępstwo skarbowe ani umorzenia tego postępowania $\mathrm{z}$ powodu przedawnienia lub amnestii (art. 110 ust. 3c ustawy o Policji).

22, ,...) prawo do nagrody rocznej uzależnione jest od wykonywania w danym roku kalendarzowym obowiązków służbowych”, I. SIERockA, Nagrody roczne funkcjonariuszy Policji, „Monitor Prawa Pracy” 3 (2012), s. 128. „(...) policjantowi przysługuje nagroda roczna za okres służby faktycznie pełnionej w danym roku kalendarzowym", wyrok WSA w Warszawie z dnia z dnia 28 lipca 2010 r., sygn. akt II SA/Wa 619/10, Legalis nr 266629; wyrok WSA w Szczecinie z dnia 16 listopada 2011 r., sygn. akt II SA/Sz 901/11, Legalis nr 396742; wyrok WSA w Szczecinie z dnia 26 stycznia 2011 r., sygn. akt II SA/Sz 785/10, Legalis nr 526363.

23 „Nagroda określona w omawianym przepisie ma charakter temporalno-motywacyjny. O temporalnym charakterze omawianej nagrody świadczy, że jest ona przyznawana co roku. Natomiast na motywacyjny charakter nagrody wskazuje, że jest ona przyznawana tylko tym policjantom, którzy pełnili służbę w sposób nienaganny”, B. OpaliŃski, M. Rogalski, P. Szustakiewicz, Uwagi do art. 110, [w:] Ustawa o Policji; P. Szustakiewicz, Stosunki stużbowe funkcjonariuszy służb mundurowych $i$ żolnierzy zawodowych jako sprawa administracyjna, Warszawa: Difin S.A. 2012, s. 210 n. 
4 ustawy o Policji, mimo braku wymaganego 6 miesięcznego okresu pełnienia służby w danym roku kalendarzowym ${ }^{24}$.

Kwestie związane z obniżeniem bądź odmową przyznania nagrody rocznej przekraczają ramy niniejszego opracowania. $Z$ uwagi na powyższe zagadnienia te nie będą przedmiotem dalszej analizy.

Prawo do nagrody rocznej, co do zasady, materializuje się po upływie roku kalendarzowego, w którym policjant pełnił służbę, natomiast wypłaca się ją do dnia 31 marca roku kalendarzowego następującego po roku, za który przysługuje nagroda (art. 110 ust. 9 ustawy o Policji). Jest to o tyle zrozumiałe, że z upływem roku kalendarzowego, za który ma być przyznana nagroda roczna, możliwe jest zsumowanie poszczególnych okresów pełnienia służby, a tym samym ustalenie, czy policjant $\mathrm{w}$ danym roku kalendarzowym pełnił ją w minimalnie wymaganym okresie 6 miesięcy (z uwzględnieniem pozostałych regulacji wynikających z art. 110 ustawy o Policji $)^{25}$. Zatem ustalenie, czy policjant nabył prawo do nagrody rocznej za dany rok kalendarzowy musi nastąpić w pierwszych trzech miesiącach roku kalendarzowego następującego po roku, za który nagroda roczna ma być przyznana, bowiem musi zostać wypłacona do tego czasu. Należy jednak odróżnić czynność samej wypłaty nagrody rocznej, która stanowi czynność stricte materialno-techniczną ${ }^{26}$ od jej przyznania (o czym w dalszej części niniejszego opracowania). Wypłata nagrody rocznej musi być bowiem poprzedzona jej przyznaniem, a to może nastąpić najwcześniej z upływem roku kalendarzowego, w którym policjant pełnił służbę, za którą nagroda roczna ma być przyznana, tj. w dniu 1 stycznia roku kalendarzowego następującego po roku, za który przysługuje nagroda, a najpóźniej w dniu 31 marca roku kalendarzowego następującego po roku, za który przysługuje nagroda, bowiem jest to ostatni dzień, w którym przepis zobowiązuje do jej wypłaty. Oczywiste jest, że przyznanie nagrody rocznej może nastąpić w tym samym dniu, w którym będzie ona wypłacona.

Zgodzić należy się zatem ze stwierdzeniem, że choć art. 110 ust. 9 ustawy o Policji określa jedynie maksymalny termin wypłaty nagrody rocznej ${ }^{27}$, to jednak z przepisu tego da się wywieść również maksymalny termin jej przyzna-

\footnotetext{
${ }^{24}$ Oczywiście, uprzednio należy ustalić, czy nie zaistniały okoliczności uzasadniające pozbawienie policjanta prawa do nagrody rocznej, o których mowa w art. 110 ust. 7 ustawy o Policji.

${ }^{25}$ Dodać również należy, że zgodnie z art. 42 ust. 6 ustawy o Policji, okres za który przyznano świadczenie pieniężne, o którym mowa w art. 42 ust. 5 ustawy o Policji, wlicza się do okresu służby uwzględnianego przy ustalaniu okresu, od którego zależy uprawnienie do nagrody rocznej.

${ }^{26}$, „...) wypłata należnej funkcjonariuszowi nagrody rocznej ma charakter czynności materialnotechnicznej", postanowienie WSA w Gliwicach z dnia 13 kwietnia 2015 r., sygn. akt IV SA/Gl 309/15, Legalis nr 1279745; wyrok WSA w Warszawie z dnia 12 marca 2015 r., sygn. akt II SA/Wa 2152/14, Legalis nr 1383374.

${ }^{27}$ ŁyżWa, ToKarski, Uposażenie, s. 592.
} 
nia, bowiem wypłata nagrody rocznej musi być poprzedzona jej przyznaniem. Z kolei z pozostałych przepisów art. 110 ustawy o Policji da się ustalić punkt na osi czasowej, w którym najwcześniej możliwe jest jej przyznanie. Policjantowi pełniącemu czynną służbę nagroda roczna za dany rok kalendarzowy może być przyznana najwcześniej po upływie tego roku. Wówczas możliwe jest ustalenie, czy zaistniały wszystkie przesłanki warunkujące jej przyznanie, a także czy nie zaistniały zdarzenia, bądź okoliczności, które obligują do odmowy jej przyznania, albo do jej obniżenia. Odmiennie natomiast przedstawia się sytuacja w przypadku zwolnienia policjanta ze służby w Policji.

Wyjątkowo wypłata nagrody rocznej policjantowi zwalnianemu ze służby następuje w terminie 14 dni od dnia zwolnienia ze służby w Policji (art. 110 ust. 10 ustawy o Policji). Oznacza to, że przyznanie tej nagrody może nastąpić najwcześniej od dnia wskazanego w wydanym rozkazie personalnym o zwolnieniu ze służby w Policji, jako dzień zwolnienia ${ }^{28}$, a ściślej z upływem tego dnia, a najpóźniej z upływem 14-tego dnia od dnia tego zwolnienia. Zatem powołany przepis art. 110 ust. 10 ustawy o Policji statuuje wyjątek od przyjętej reguły, umożliwiający policjantowi nabycie prawa do nagrody rocznej jeszcze w tym samy roku kalendarzowym, w którym pełnił służbę, za który ma być przyznana nagroda roczna, tj. jeszcze przed upływem tego roku kalendarzowego. Analogicznie w przypadku śmierci policjanta albo jego zaginięcia, należną mu nagrodę roczną wypłaca się małżonkowi ${ }^{29}$, a w dalszej kolejności dzieciom oraz rodzicom uprawnionym do renty rodzinnej ${ }^{30}$. Śmierć policjanta powoduje

${ }^{28}$ Rozkaz personalny o zwolnieniu ze służby w Policji wskazuje bowiem zarówno podstawę zwolnienia z tej służby, jak i datę zwolnienia. Umożliwia to tym samym ustalenie okresu wymaganego do nabycia prawa do nagrody rocznej, a także czy nie zaistniał wyjątek określony w art. 110 ust. 4 pkt 3 ustawy o Policji, który uprawnia do przyznania nagrody rocznej mimo braku wymaganego okresu służby w roku kalendarzowym, za który nagroda ma być przyznana, o którym mowa w art. 110 ust. 3 ustawy o Policji. Ostateczna decyzja w tej sprawie, albo nieostateczna, której nadano rygor natychmiastowej wykonalności (art. 108 § 1 k.p.a.) umożliwia w sposób niebudzący wątpliwości ustalić wyżej wymienione okoliczności. „Między decyzją o zwolnieniu ze służby a decyzją o przyznaniu nagrody rocznej istnieje związek prawny (iunctim), bowiem decyzja o przyznaniu nagrody za część roku 2014 jest konsekwencją prawną wcześniejszej decyzji o zwolnieniu ze służby. Stanowi o tym art. 110 ust. 10 ustawy o Policji, według którego policjantowi zwalnianemu ze służby nagrodę roczną wypłaca się w terminie 14 dni od dnia zwolnienia. Zatem jedną z konsekwencji prawnych zwolnienia ze służby jest przyznanie nagrody za okres przypadający w danym roku”, wyrok WSA w Białymstoku z dnia 9 września 2014 r., sygn. akt II SA/Bk 648/14, Legalis nr 1116674

29 „Należy podkreślić, że w przypadku małżonka wymaga się jedynie pozostawania w ważnym związku małżeńskim. Nie ma znaczenia w tym względzie pozostawanie we wspólnym gospodarstwie domowym", Sierocka, Nagrody, s. 131.

30 „Inaczej w odniesieniu do dzieci i rodziców. Osoby te upoważnione są do nagrody, jeżeli jednocześnie uprawnione są do renty rodzinnej z tytułu śmierci lub zaginięcia funkcjonariusza", Sierocka, Nagrody, s. 131. 
ustanie stosunku służbowego ${ }^{31}$. Zatem przepis art. 110 ust. 10 ustawy o Policji, w tym zakresie należy stosować odpowiednio (art. 110 ust. 11 ustawy o Policji). Przyznanie nagrody rocznej powinno nastąpić wobec tego najwcześniej z dniem śmierci policjanta albo uznania go za zaginionego ${ }^{32}$, a najpóźniej z upływem 14-stu dni od tego dnia, bowiem w tym dniu, zgodnie $\mathrm{z}$ art. 110 ust. 10 ustawy o Policji, wypłaca się należną policjantowi nagrodę roczną uprawnionym członkom jego rodziny. W obydwu omawianych przypadkach nie zwalania to jednak z obowiązku zbadania wymaganego okresu pełnienia przez policjanta służby w danym roku kalendarzowym i ustalenia wymaganego minimalnego okresu pełnienia przez niego służby w tym roku kalendarzowym (oczywiście z uwzględnieniem pozostałych regulacji wynikających z art. 110 ustawy o Policji).

Podmiotem uprawnionym do przyznania nagrody rocznej jest przełożony właściwy w sprawach mianowania policjanta na stanowisko służbowe, przeniesienia oraz zwolnienia go z tego stanowiska (art. 110 ust. 13 ustawy o Policji). Jeżeli jednak policjant $\mathrm{w}$ danym roku kalendarzowym pełnił służbę $\mathrm{w}$ różnych jednostkach organizacyjnych Policji, nagrodę roczną przyznaje się i wypłaca w jednostce, która była w danym roku kalendarzowym ostatnim miejscem pełnienia przez policjanta służby (art. 110 ust. 12 ustawy o Policji). Wynika z tego, że uprawniony do przyznania nagrody rocznej jest przełożony właściwy w sprawach osobowych policjanta, o którym mowa w art. 32 ust. 1 ustawy o Policji, będący jednocześnie kierownikiem ostatniej jednostki Policji ${ }^{33}$, w której policjant pełnił służbę w roku kalendarzowym, za który nagroda roczna ma być przyznana. Policjant może bowiem pełnić służbę w danym roku kalendarzowym w różnych jednostkach organizacyjnych Policji, a zatem podlegać różnym kierownikom tych jednostek Policji. Mógł tym samym podlegać różnym przełożonym właściwym w sprawach osobowych. Właściwy do przyznania nagrody rocznej będzie ten przełożony właściwy w sprawach osobowych policjanta, który był tym przeło-

\footnotetext{
${ }^{31}$ Zgodnie z $§ 1$ pkt 8 rozporządzenia Ministra Spraw Wewnętrznych z dnia 14 maja 2013 r. w sprawie szczegółowych praw i obowiązków oraz przebiegu służby policjantów (Dz. U. poz. 644 z póżn. zm.) przez ustanie stosunku służbowego należy rozumieć jego rozwiązanie w związku ze zwolnieniem policjanta ze służby lub jego śmiercią. Natomiast M. Wieczorek postuluje de lege ferenda, aby zaginięcie policjanta również było podstawą wygaśnięcia stosunku służbowego wzorem innych pragmatyk służbowych, WieczoreK, Charakter, s. $291 \mathrm{n}$.

32 Jeżeli organ jest w posiadaniu tej informacji (np. w sytuacji śmierci policjanta na służbie). $\mathrm{W}$ innych przypadkach, zasadne jest, aby termin ten liczony był od dnia uzyskania takiej informacji przez organ.

${ }^{33}$ Albo też kierownikiem jednostki Policji nadrzędnej wobec jednostki Policji, w której policjant pełnił służbę np. komendant miejski (powiatowy) Policji, jeśli policjant pełnił służbę w komisariacie Policji, albo też komendant wojewódzki Policji, jeśli policjant pełnił służbę w komisariacie kolejowym, wodnym, lotniczym lub innym komisariacie specjalistycznym.
} 
żonym w dniu 31 grudnia roku kalendarzowego, za który nagroda roczna ma być przyznana, a nie aktualny przełożony właściwy w sprawach osobowych policjanta, w szczególności nie musi nim być przełożony właściwy w sprawach osobowych policjanta, który stał się nim w roku kalendarzowym następującym po roku, za który przysługuje nagroda.

Należy również zaznaczyć, że Komendantowi Głównemu Policji oraz jego zastępcom nagrodę roczną przyznaje minister właściwy do spraw wewnętrznych. Komendanta Głównego Policji powołuje i odwołuje bowiem Prezes Rady Ministrów na wniosek ministra właściwego do spraw wewnętrznych (art. 5 ust. 3 ustawy o Policji), natomiast zastępców Komendanta Głównego Policji, w tym I Zastępcę, powołuje i odwołuje minister właściwy do spraw wewnętrznych na wniosek Komendanta Głównego Policji (art. 5 ust. 4 ustawy o Policji). Zatem podmioty te nie posiadają przełożonego właściwego do mianowania na te stanowiska służbowe, bowiem są oni powoływani na te stanowiska, a powołują ich podmioty zewnętrzne usytuowane poza hierarchiczną strukturą organizacyjną Policji. Z kolei nagrody roczne Komendantowi Centralnego Biura Śledczego Policji, dowódcy Biura Operacji Antyterrorystycznych, komendantom wojewódzkim Policji, Komendantowi Stołecznemu Policji, komendantom szkół policyjnych i ich zastępcom oraz rektorowi Wyższej Szkoły Policji w Szczytnie i osobie pełniącej w uczelni służb państwowych funkcję kierowniczą do spraw realizacji zadań uczelni jako jednostki organizacyjnej właściwej służby przyznaje Komendant Główny Policji. Wyjątek stanowi także Komendant Biura Spraw Wewnętrznych Policji oraz jego zastępcy, którym nagrodę roczną przyznaje minister właściwy do spraw wewnętrznych na wniosek Inspektora Nadzoru Wewnętrznego (art. 110 ust. 15 ustawy o Policji).

Przyznanie, obniżenie, bądź odmowa przyznania nagrody rocznej następuje w drodze decyzji administracyjnej, od której policjantowi (a także byłemu policjantowi, w przypadku zwolnienia go ze służby w Policji) przysługuje odwołanie w administracyjnym toku instancji do wyższego przełożonego (art. 110 ust. 8c ustawy o Policji). Decyzja tego ostatniego jest ostateczna i może być zaskarżona na drodze sądowoadministracyjnej ${ }^{34}$. Zatem wyłącznie przyznanie, obniżenie, albo odmowa przyznania nagrody rocznej stanowi przedmiot sprawy administracyjnej w rozumieniu art. 1 ustawy z dnia 14 czerwca 1960 r. Kodeks postępowania administracyjnego ${ }^{35}$. Organ administracyjny, tj. przełożony, o którym mowa w art.

${ }^{34}$ Wyrok NSA z dnia 5 stycznia 2017 r., sygn. akt I OSK 1934/15, Legalis nr 1722029; wyrok WSA w Warszawie z dnia 12 marca 2015 r., sygn. akt II SA/Wa 2152/14.

${ }^{35}$ Ustawa z dnia 14 czerwca 1960 r. Kodeks postępowania administracyjnego, Dz. U. z 2020 r., poz. $256 \mathrm{z}$ późn. zm. 
110 ust. 13 ustawy o Policji, zobowiązany jest w ramach prowadzonego postępowania administracyjnego do ustalenia wyłącznie przesłanek warunkujących przyznanie policjantowi nagrody rocznej za dany rok kalendarzowy. Oznacza to, że winien on zbadać wyłącznie kwestie związane z minimalnym okresem pełnienia przez policjanta służby w roku kalendarzowym, za który nagroda ma być przyznana, z uwzględnieniem regulacji odnoszących się do okresów, które nie mogą zostać wliczone do okresu pełnionej przez policjanta służby w danym roku kalendarzowym, wyjątków umożliwiających przyznanie tej nagrody mimo braku wymaganego minimalnego okresu pełnionej służby w danym roku kalendarzowym, a także okoliczności skutkujących obniżeniem, bądź odmową przyznania tej nagrody. Wobec tego rozstrzygnięcie w tej sprawie winno ograniczyć się do wskazania, czy nagroda roczna zostaje przyznana, obniżona, albo nieprzyznana za dany rok kalendarzowy ${ }^{36}$. Przyznanie nagrody rocznej musi odnosić się do konkretnego roku kalendarzowego, bowiem tylko to umożliwia zbadanie, czy policjant w takim roku kalendarzowym spełniał wymogi do jej przyznania. Przyznanie nagrody rocznej bez odniesienia się do konkretnego roku kalendarzowego, za który nagroda przysługuje, tj. in abstracto, stanowi wadę kwalifikowaną decyzji administracyjnej, skutkującą koniecznością wyeliminowania jej z obrotu prawnego jako rażąco naruszającej prawo (art. $156 \S 1$ pkt 2 k.p.a.). Tym samym osnowa decyzji nie rozstrzyga o wysokości przyznanej nagrody rocznej. Jest to czynność materialno-techniczna, która obciąża komórki organizacyjne właściwe do spraw finansowych jednostek Policji. Obliczenia wysokości należnej policjantowi nagrody rocznej można natomiast dokonać jedynie w oparciu o ostateczną decyzję administracyjną przyznającą nagrodę roczną, albo nieostateczną decyzję, której nadano rygor natychmiastowej wykonalności, zgodnie z art. $108 \S 1$ k.p.a. Obliczenie wysokości należnej nagrody rocznej i następnie jej wypłata stanowią czynności następcze względem przyznania nagrody rocznej, które mogą być wykonane wyłącznie w oparciu o wydaną decyzję administracyjną w sprawie przyznania, obniżenia, albo odmowy przyznania nagrody rocznej.

36, „(..) przedmiotem rozstrzygnięć przełożonego jest «przyznanie, obniżenie lub odmowa przyznania nagrody rocznej». Brak użycia w sentencji ww decyzji sformułowania w literalnym brzmieniu art. 110 ust. 8c ww ustawy [ustawy o Policji - P.G.] «odmawiam przyznania nagrody rocznej», nie dyskwalifikuje ww rozstrzygnięcia”, wyrok WSA w Warszawie z dnia 22 września 2016 r., sygn. akt II SA/Wa 447/16, Legalis nr 1589856. Należy tylko dodać, że rozstrzygnięcie zawierało stwierdzenie, że „nie przysługuje nagroda roczna za okres służby pełnionej w roku (...)”. 


\section{PRZYZNANIE NAGRODY ROCZNEJ \\ W PRZYPADKU ZWOLNIENIA ZE SŁUŻBY W POLICJI \\ NA PODSTAWIE ART. 41 UST. 2 PKT 5 USTAWY O POLICJI}

Jak już wcześniej wskazano, prawo do nagrody rocznej, co do zasady, materializuje się po upływie roku kalendarzowego, za który nagroda ma być przyznana. Wyjątkiem jest zwolnienie ze służby, które umożliwia zwalnianemu policjantowi nabycie uprawnienia do nagrody rocznej jeszcze w tym samym roku kalendarzowym, za który ma być ona przyznana, tj. w roku kalendarzowym, w którym nastąpiło zwolnienie ze służby w Policji. Odstępstwo to nie zwalnia z konieczności zbadania, czy w roku, w którym nastąpiło zwolnienie ze służby, policjant nabył prawo do nagrody rocznej, a zatem czy pełnił służbę w wymaganym okresie czasu. Jeżeli pełnił tę służbę przez okres krótszy niż wynika to z art. 110 ust. 3 ustawy o Policji, wówczas nie może nabyć tego prawa. Zgodnie z tym przepisem nagroda roczna przysługuje, jeżeli policjant $\mathrm{w}$ danym roku kalendarzowym pełnił służbę przez okres co najmniej 6 miesięcy kalendarzowych. Konieczne jest jednak pewne uzupełnienie. Kluczowa jest bowiem podstawa zwolnienia ze służby w Policji. Jak wynika wprost z treści art. 110 ust. 4 pkt 3 ustawy o Policji, warunku, o którym mowa w art. 110 ust. 3 ustawy o Policji, nie stosuje się przy ustalaniu uprawnień do nagrody rocznej za rok kalendarzowy, w którym policjant został zwolniony ze służby w Policji w związku z nabyciem uprawnień do emerytury lub renty, bądź na podstawie art. 41 ust. 2 pkt 6 albo 7 ustawy o Policji. Powołany przepis systematyzuje przyjęte wyjątki $\mathrm{w}$ dwóch odrębnych grupach. Pierwszą grupę stanowią przesłanki umożliwiające nabycie prawa do nagrody rocznej, mimo braku wymogu 6-miesięcznej służby w roku kalendarzowym, które związane są podstawami zwolnieniowymi ze służby w Policji w związku z nabyciem uprawnień do emerytury lub renty. Drugą grupę stanowią enumeratywnie wskazane podstawy zwolnieniowe, tj. art. 41 ust. 2 pkt 6 albo 7 ustawy o Policji. Zastosowanie art. 110 ust. 4 pkt 3 ustawy o Policji wymaga zatem ustalenia, czy istnieje funkcjonalny związek między nabyciem uprawnienia do emerytury lub renty a zwolnieniem ze służby, albo czy podstawą zwolnienia policjanta ze służby w Policji jest art. 41 ust. 2 pkt 6 albo 7 ustawy o Policji. Należy również dodać, że wymieniony katalog podstaw zwolnienia ze służby, tj. art. 41 ust. 2 pkt 6 albo 7 ustawy o Policji, nie ma charakteru przykładowej egzemplifikacji, ale jest katalogiem zamkniętym. Wskazane expressis verbis $\mathrm{w}$ art. 110 ust. 4 pkt 3 ustawy o Policji dwie podstawy zwolnieniowe, tj. art. 41 ust. 2 pkt 6 albo 7 ustawy o Policji, nie muszą mieć także żadnego związku z nabyciem przez policjanta uprawnień do emerytury lub renty. Nabycie przez policjanta uprawnienia do emerytury lub renty jest irrelewantne z punktu widzenia możliwości zastosowania tych podstaw do zwolnienia funkcjonariusza ze służby 
w Policji. Warunkiem wystarczającym, umożliwiającym policjantowi nabycie prawa do nagrody rocznej za rok kalendarzowy, w którym nastąpiło zwolnienie go ze służby w Policji, bez konieczności spełnienia warunku, o którym mowa w art. 110 ust. 3 ustawy o Policji, jest ustalenie, że zwolnienie ze służby w Policji nastąpiło na podstawie art. 41 ust. 2 pkt 6 ustawy o Policji, tj. z powodu likwidacji jednostki Policji lub jej reorganizacji połączonej ze zmniejszeniem obsady etatowej, jeśli przeniesienie policjanta do innej jednostki lub na niższe stanowisko nie jest możliwe, albo na podstawie art. 41 ust. 2 pkt 7 ustawy o Policji, tj. z powodu upływu 12 miesięcy od dnia zaprzestania przez policjanta służby w powodu choroby, i to niezależnie od tego, czy policjant ten nabył uprawnienie do emerytury lub renty czy też nie. Dodać, również należy, że powołany przepis art. 110 ust. 4 pkt 3 ustawy o Policji nie wymienia precyzyjnie innych podstaw zwolnienia, jednak wskazuje, że pozostałe podstawy zwolnieniowe (prócz podstaw wskazanych w art. 41 ust. 2 pkt 6 albo 7 ustawy o Policji), objęte tym przepisem, muszą nastąpić w związku $\mathrm{z}$ nabyciem przez policjanta uprawnień do emerytury lub renty. Zastosowanie wobec tego podstaw zwolnieniowych uprawniających do nabycia nagrody rocznej mimo braku wymaganego 6-miesięcznego okresu pełnienia służby w danym roku kalendarzowym wymaga wykazania, iż podstawy te są stricte związane z nabyciem prawa do emerytury lub renty, z tym jednak zastrzeżeniem, że podstawy tej nie może stanowić ani art. 41 ust. 2 pkt 6 ani art. 41 ust. 2 pkt 7 ustawy o Policji, bowiem, jak to zostało wcześniej powiedziane, podstawy te uprawniają do nabycia nagrody rocznej ipso facto ich zastosowania, bez konieczności wykazywania związku z nabyciem uprawnień do emerytury lub renty.

Zatem zwolnienie ze służby w Policji na podstawie art. 41 ust. 2 pkt 5 ustawy o Policji nie uprawnia do automatycznego nabycia przez zwalnianego policjanta prawa do nagrody rocznej, jeśli nie spełnia on wymogów określonych w art. 110 ustawy o Policji, a w szczególności warunku odnoszącego się do minimalnego okresu służby w roku kalendarzowym, w którym nastąpiło zwolnienie ze służby. Podstawa zwolnienia ze służby ze względu na ważny interes służby, tj. art. 41 ust. 2 pkt 5 ustawy o Policji, nie została wprost wskazana w treści przepisu art. 110 ust. 4 pkt 3 ustawy o Policji (tak jak dwie inne podstawy zwolnieniowe, tj. wynikające z art. 41 ust. 2 pkt 6 albo 7 ustawy o Policji), a także nie pozostaje $\mathrm{w}$ funkcjonalnym związku z nabyciem przez zwalnianego policjanta uprawnień do emerytury lub renty. Jest całkowicie niezależna od nabycia prawa do emerytury lub renty. Zatem rozwiązanie stosunku służbowego na tej podstawie prawnej nie pozwala na uznanie, że wystąpiła przesłanka określona $\mathrm{w}$ art. 110 ust. 4 pkt 3 ustawy o Policji, chociażby policjant zwalniany na tej podstawie posiadał uprawnienia emerytalne lub rentowe. 
Odmienne założenie nie wytrzymuje krytyki. Nie można bowiem założyć a limine, że podstawa zwolnieniowa określona w art. 41 ust. 2 pkt 5 ustawy o Policji, objęta jest tą częścią normy prawnej wynikającej z przepisu art. 110 ust. 4 pkt 3 ustawy o Policji, która uprawnia do nagrody rocznej policjanta zwolnionego ze służby, bez konieczności spełnienia wymogu określonego w art. 110 ust. 3 ustawy o Policji, bo ma ona związek z nabyciem uprawnień do emerytury lub renty. Jak słusznie podkreśla doktryna, wykładnia ustawy to nie tylko wydobycie sensu z wyrażenia, lecz ponadto wybór spośród rozmaitych znaczeń, jakie z tekstu wynikają, tego znaczenia, które jest trafne i miarodajne ${ }^{37}$. Jej celem jest zatem wydobycie sensu normy prawnej, ustalenie jej właściwego rozumienia lub też przypisanie jej odpowiedniego znaczenia bądź wyznaczenie odpowiedniego zakresu znaczeniowego z treści danego przepisu prawa. Wobec tego, punktem odniesienia powinna być wykładnia językowa, polegająca na ustaleniu znaczenia i zakresu zastosowanych w przepisie wyrażeń tekstu prawnego ze względu na język, w którym zostały sformułowane. Nie może budzić wątpliwość, że ustawodawca w treści art. 110 ust. 3 ustawy o Policji uzależnił przyznanie policjantowi nagrody rocznej od spełnienia warunku temporalnego, polegającego na pełnieniu przez niego $\mathrm{w}$ danym roku kalendarzowym służby przez co najmniej 6 miesięcy. Przypadki wskazane w art. 110 ust. 4 ustawy o Policji stanowią wyjątki od tak ustanowionej reguły. Dopuszczają możliwość przyznania nagrody rocznej mimo niespełnienia warunku odnoszącego się do (okresu) czasu pełnionej przez policjanta służby w danym roku kalendarzowym. Charakter przepisów statuujących instytucję nagrody rocznej, a zwłaszcza art. 110 ust. 1 ustawy o Policji, stanowiącego podstawę prawną tej konstrukcji prawnej, a także art. 110 ust. 3 ustawy o Policji, określającego warunki konieczne, umożliwiające nabycie tego prawa, świadczy dobitnie o tym, iż celem ustawodawcy było ustanowienie dla policjanta określonego uprawnienia o charakterze majątkowym w zamian za rzeczywiście pełnioną (świadczoną) przez niego służbę w danym roku kalendarzowym. Co do zasady bowiem regulacja ta umożliwia nabycie przez policjanta roszczenia do tej nagrody, jednak po spełnieniu warunku określonego w art. 110 ust. 3 ustawy o Policji. Przepis art. 110 ust. 4 ustawy o Policji ustanawia natomiast przypadki, które zwalniają z konieczności spełnienia określonych przesłanek, od których uzależnione jest nabycie prawa do nagrody rocznej. Ustanowienie określonego odstępstwa od przyjętej reguły zobowiązuje zatem do literalnej wykładni normy zawartej w art. 110 ust. 4 ustawy o Policji. Zastosowanie wykładni rozszerzającej prowadziłoby natomiast do uzyskania znaczenia tego przepisu, które uwzględniałoby przypadki nim nieobjęte.

37 J. Nowacki, Z. TовоR, Wstęp do prawoznawstwa, Katowice: Naukowa Oficyna Wydawnicza 1997, s. 191. 
Jak już wcześniej zaznaczono, podstawa zwolnieniowa z art. 41 ust. 2 pkt 5 ustawy o Policji nie została wprost wskazana w art. 110 ust. 4 pkt 3 ustawy o Policji. Nie może być też uznana za podstawę zwolnieniową, która funkcjonalnie związana jest z nabyciem uprawnień do emerytury lub renty, chociażby w chwili zwolnienia policjant posiadał takie uprawnienia.

Analizując przesłankę zawartą w przepisie art. 41 ust. 2 pkt 5 ustawy o Policji należy ustalić granice znaczeniowe pojęcia „ważnego interesu służby”. Jest ona bowiem jedyną przesłanką istotną z punktu widzenia przedmiotu postępowania administracyjnego, w rozumieniu art. 1 k.p.a., prowadzonego na podstawie art. 41 ust. 2 pkt 5 ustawy o Policji. Ustalenie istnienia ważnego interesu służby, przemawiającego za zwolnieniem policjanta ze służby w Policji jest zatem jedynym faktem prawotwórczym stanowiącym podstawę do zastosowania tej konstrukcji prawnej. Granice konkretnej sprawy administracyjnej, wytyczone przez poszczególne podstawy zwolnieniowe zamieszczone w pragmatyce służbowej, zobowiązujące albo umożliwiające zwolnienie policjanta ze służby w Policji determinują również organ do wykonania określonych czynności w ramach konkretnego postępowania. Organ nie jest uprawniony do wykroczenia poza ustalony, przez konkretną podstawę zwolnieniową, przedmiot sprawy. Nie może go również w żaden sposób modyfikować (zmieniać lub rozszerzać) w toku prowadzonego postępowania, zainicjowanego na konkretnej podstawie zobowiązującej albo umożliwiającej zwolnienie policjanta ze służby w Policji. Stąd też organ administracyjny wszczynając postępowanie administracyjne $\mathrm{w}$ sprawie zwolnienia policjanta ze służby w Policji zobowiązany jest do ustalenia czy istnieje ważny interes służby, który w tym konkretnym przypadku powoduje konieczność zwolnienia policjanta ze służby w Policji. Nie jest natomiast uprawniony do badania czy policjant ten nabył uprawnienia do emerytury lub renty. Fakt nabycia tego uprawnienia nie ma żadnego znaczenia w kontekście przedmiotu tego postępowania, a w szczególności decyzji merytorycznej zwalniającej policjanta ze służby w Policji.

Z kolei pojęcie „ważny interes służby” stanowi klauzulę generalną, co oznacza, że nie zostało ono bliżej sprecyzowane w ustawie o Policji ${ }^{38}$. Jak słusznie wskazuje judykatura „Nie może jednak ulegać wątpliwości, że przy odczytywaniu treści powyższego terminu należy sięgnąć przede wszystkim do przepisów regulujących cele i zadania Policji oraz szczególny status funkcjonariuszy tej formacji. W rachubę może zatem wchodzić realnie istniejąca przyczyna albo szereg okoliczności czy zdarzeń świadczących o tym, że dalsze pozostawanie policjanta w służbie koliduje $\mathrm{z}$ interesami Policji, a zatem że funkcjonariusz ten z przyczyn merytorycznych dla

${ }^{38}$ Wyrok NSA z dnia 24 lipca 2013 r., sygn. akt I OSK 1969/12, Legalis nr 764628. 
dobra macierzystej formacji nie powinien kontynuować w niej służby"39. Oznacza to tym samym, że istnienie przesłanki „ważnego interesu służby” musi być rozważane na tle stanu faktycznego określonej sprawy. Niezbędne jest również wykazanie realnie istniejącej przyczyny lub szeregu okoliczności czy zdarzeń świadczących łącznie o tym, że dalsze pozostawanie policjanta w służbie nie jest możliwe ${ }^{40}$. Przyczyny zwolnienia ze służby w Policji objęte podstawą zwolnieniową określoną w art. 41 ust. 2 pkt 5 ustawy o Policji odwołują się do okoliczności lub zdarzeń związanych zarówno z zachowaniem samego funkcjonariusza w służbie, jak i w życiu prywatnym, a także do okoliczności, na powstanie których nie miał on decydującego wpływu, lecz których zaistnienie utrudnia lub wręcz uniemożliwia dalsze pełnienie przez niego służby. Ustawodawca pozostawił zatem organowi administracyjnemu luz decyzyjny ${ }^{41}$, który uprawnia go do skonkretyzowania norm zawartych w przepisie art. 41 ust. 2 pkt 5 ustawy o Policji, stanowiących klauzulę generalną. W konsekwencji rolą organu jest wykazanie, że za zwolnieniem policjanta na powołanej podstawie prawnej przemawia ważny interes służby, bądź innymi słowy, wykazanie, że zachowanie policjanta lub inne okoliczności z nim związane świadczą o tym, iż pozostawienie go w służbie narusza jej ważny interes. Warto również dodać, że „Na podstawie art. 41 ust. 2 pkt 5 ustawy o Policji dopuszczalne jest rozwiązanie stosunku służbowego z policjantem, który w ocenie przełożonych nie powinien pełnić służby z przyczyn pozamerytorycznych, ale nie można zwolnić go ze służby na innej fakultatywnej lub obligatoryjnej podstawie określonej w ustawie o Policji”,42.

Skoro zatem podstawa wskazana w art. 41 ust. 2 pkt 5 ustawy o Policji nie odwołuje się bezpośrednio do nabycia przez policjanta uprawnień do emerytury lub renty, a wyłącznie do istnienia „ważnego interesu służby”, to bezpodstawne byłoby utożsamianie tej podstawy zwolnieniowej jako podstawy związanej z nabyciem uprawnień do emerytury lub renty, nawet $\mathrm{w}$ przypadku, gdyby policjant zwolniony na tej podstawie, w chwili zwolnienia, nabył uprawnienia do emerytury lub renty. Nabycie uprawnień do emerytury lub renty stanowi okoliczność, która pozostaje poza granicami sprawy administracyjnej wytyczonej przez podstawę

\footnotetext{
${ }^{39}$ Wyrok NSA z dnia 29 lipca 2014 r., sygn. akt I OSK 1853/13, Legalis 1068518; wyrok NSA z dnia 11 stycznia 2017 r., sygn. akt I OSK 2386/16, 1722001.

${ }^{40}$ Wyrok NSA z dnia 24 lipca 2013 r., sygn. akt I OSK 1969/12; wyrok NSA z dnia 7 lutego 2019 r., sygn. akt I OSK 1094/17, Legalis nr 1884249; wyrok NSA z dnia 27 października 2016 r., sygn. akt I OSK 1111/15, Legalis nr 1553678 - i powołany tam wyrok NSA z dnia 21 kwietnia 1999 r., sygn. akt II SA 426/99, LEX nr 47389.

${ }^{41}$ Wyrok NSA z dnia 7 lipca 2016 r., sygn. akt I OSK 3445/15, Legalis nr 1511317.

42 Wyrok NSA z dnia 12 marca 2015 r., sygn. akt I OSK 723/14, Legalis nr 1310807; wyrok NSA z dnia 6 czerwca 2014 r., sygn. akt I OSK 1118/13, Legalis nr 1328236.
} 
zwolnieniową określoną w art. 41 ust. 2 pkt 5 ustawy o Policji. Trudno natomiast sobie wyobrazić, iż fakt nabycia przez policjanta uprawnienia do emerytury lub renty stanowiłby okoliczność, która godziłaby w dobro prawnie chronione, jakim jest „ważny interes służby”, a tym samym, który determinowałby organ administracyjny do zainicjowania postępowania w sprawie zwolnienia ze służby w Policji na tej podstawie z tych właśnie przyczyn, zwłaszcza, że nabycie prawa do emerytury $z$ tytułu osiągnięcia 30 lat wysługi emerytalnej stanowi podstawę do zwolnienia policjanta ze służby w Policji na innej podstawie, tj. art. 41 ust. 2 pkt 4 ustawy o Policji.

\section{ZAKOŃCZENIE}

Służba w Policji to szczególny rodzaj służby publicznej wymagającej od funkcjonariusza pełnej dyspozycyjności i podporządkowania w służbie. Cele i zadania Policji, określone w ustawie o Policji, wymagają zapewnienia rzeczywistych wykonawców tych zadań. Stąd też pragmatyka służbowa przewiduje szereg przywilejów, mających być w założeniu pewną rekompensatą za rzeczywiście wykonywaną (świadczoną) przez policjanta służbę. Jednym z nich jest instytucja nagrody rocznej, uregulowana $\mathrm{w}$ art. 110 ustawy o Policji.

Nabycie uprawnienia do nagrody rocznej, co do zasady, zostało uzależnione od okresu pełnionej służby w roku kalendarzowym, za który nagroda ma być przyznana. Wyjątki od tak przyjętej reguły, które także zostały przewidziane w ustawie o Policji, muszą być zatem interpretowane w sposób rygorystyczny, bowiem przewidują odstępstwo, a tym samym stanowią wyłom od ustalonej zasady. Jednym z takich odstępstw jest art. 110 ust. 4 pkt 3 ustawy o Policji, który uprawnia do nabycia nagrody rocznej policjanta zwalnianego ze służby, mimo braku wymaganego przez art. 110 ust. 3 ustawy o Policji okresu pełnionej służby, z tym jednak zastrzeżeniem, że podstawą zwolnienia musi być art. 41 ust. 2 pkt 6 albo 7 ustawy o Policji, albo podstawa zwolnienia musi mieć związek z nabyciem przez policjanta uprawnień do emerytury lub renty. Tym samym zwolnienie policjanta ze służby w Policji na podstawie art. 41 ust. 2 pkt 5 ustawy o Policji uprawnia go do nabycia nagrody rocznej pod warunkiem pełnienia przez niego tej służby w roku kalendarzowym, w którym nastąpiło zwolnienie, przez okres wskazany w art. 110 ust. 3 ustawy o Policji. Nie sposób natomiast przyjąć, by podstawa zwolnieniowa zawarta $\mathrm{w}$ art. 41 ust. 2 pkt 5 ustawy o Policji miała bezpośredni związek z nabyciem uprawnień do emerytury lub renty przez policjanta. Jak wykazano okoliczność ta nie jest badana w toku prowadzonego przez organ postępowania administracyjnego w sprawie zwolnienia ze służby w Policji, a zatem 
pozostaje ona poza granicami sprawy administracyjnej, będącej przedmiotem tego postępowania, nawet w sytuacji gdyby zwalniany na podstawie art. 41 ust. 2 pkt 5 ustawy o Policji funkcjonariusz, w chwili zwolnienia posiadał takie uprawnienia. Podstawa zwolnienia ze służby w Policji wynikająca z art. 41 ust. 2 pkt 5 ustawy o Policji nie jest zatem objęta treścią przepisu art. 110 ust. 4 pkt 3 ustawy o Policji, wobec czego brak jest podstaw do odniesienia tego uregulowania, będącego odstępstwem od ustanowionej zasady, do sytuacji, w których następuje zwolnienie ze służby na podstawie art. 41 ust. 2 pkt 5 ustawy o Policji, a zwalniany policjant nie pełnił w roku kalendarzowym, za który nagroda miałaby być przyznana służby w wymaganym przez art. 110 ust. 3 ustawy o Policji wymiarze czasu.

\section{BIBLIOGRAFIA}

\section{ŹRÓDŁA PRAWA}

Ustawa z dnia 6 kwietnia 1990 r. o Policji, Dz. U. z 2020 r., poz. 360 z późn. zm. Ustawa z dnia 26 czerwca 1974 r. Kodeks pracy, Dz. U. z 2019 r., poz. 1040 z późn. zm.

Ustawa z dnia 14 czerwca 1960 r. Kodeks postępowania administracyjnego, Dz. U. z 2020 r., poz. $256 \mathrm{z}$ późn. zm.

Rozporządzenie Ministra Spraw Wewnętrznych z dnia 14 maja 2013 r. w sprawie szczegółowych praw i obowiązków oraz przebiegu służby policjantów, Dz. U. poz. 644 z późn. zm.

\section{ORZECZNICTWO:}

Wyrok Naczelnego Sądu Administracyjnego z dnia 21 kwietnia 1999 r., sygn. akt II SA 426/99, LEX nr 47389.

Wyrok Naczelnego Sądu Administracyjnego z dnia 16 grudnia 2010 r., sygn. akt I OSK 962/10, Legalis nr 307954.

Wyrok Naczelnego Sądu Administracyjnego z dnia 24 lipca 2013 r., sygn. akt I OSK 1969/12, Legalis $\mathrm{nr} 764628$.

Wyrok Naczelnego Sądu Administracyjnego z dnia 6 czerwca 2014 r., sygn. akt I OSK 1118/13, Legalis nr 1328236.

Wyrok Naczelnego Sądu Administracyjnego z dnia 29 lipca 2014 r., sygn. akt I OSK 1853/13, Legalis 1068518.

Wyrok Naczelnego Sądu Administracyjnego z dnia 12 marca 2015 r., sygn. akt I OSK 723/14, Legalis nr 1310807.

Wyrok Naczelnego Sądu Administracyjnego z dnia 7 lipca 2016 r., sygn. akt I OSK 3445/15, Legalis nr 1511317.

Wyrok Naczelnego Sądu Administracyjnego z dnia 27 października 2016 r., sygn. akt I OSK 1111/15, Legalis nr 1553678.

Wyrok Naczelnego Sądu Administracyjnego z dnia 5 stycznia 2017 r., sygn. akt I OSK 1934/15, Legalis nr 1722029. 
Wyrok Naczelnego Sądu Administracyjnego z dnia 11 stycznia 2017 r., sygn. akt I OSK 2386/16, 1722001.

Wyrok Naczelnego Sądu Administracyjnego z dnia 17 maja 2017 r., sygn. akt I OSK 3436/15, Legalis nr 1652050.

Wyrok Naczelnego Sądu Administracyjnego z dnia 7 lutego 2019 r., sygn. akt I OSK 1094/17, Legalis nr 1884249 .

Wyrok Wojewódzkiego Sądu Administracyjnego w Warszawie z dnia z dnia 28 lipca 2010 r., sygn. akt II SA/Wa 619/10, Legalis nr 266629.

Wyrok Wojewódzkiego Sądu Administracyjnego w Szczecinie z dnia 26 stycznia 2011 r., sygn. akt II SA/Sz 785/10, Legalis nr 526363.

Wyrok Wojewódzkiego Sądu Administracyjnego w Szczecinie z dnia 16 listopada 2011 r., sygn. akt II SA/Sz 901/11, Legalis nr 396742.

Wyrok Wojewódzkiego Sądu Administracyjnego w Białymstoku z dnia 9 września 2014 r., sygn. akt II SA/Bk 648/14, Legalis nr 1116674.

Wyrok Wojewódzkiego Sądu Administracyjnego w Warszawie z dnia 12 marca 2015 r., sygn. akt II SA/Wa 2152/14, Legalis nr 1383374.

Wyrok Wojewódzkiego Sądu Administracyjnego w Warszawie z dnia 22 września 2016 r., sygn. akt II SA/Wa 447/16, Legalis nr 1589856.

Wyrok Wojewódzkiego Sądu Administracyjnego w Krakowie z dnia 23 sierpnia 2017 r., sygn. akt III SA/Kr 622/17, Legalis nr 1665440.

Wyrok Wojewódzkiego Sądu Administracyjnego w Bydgoszczy z dnia 17 października 2018 r., sygn. akt II SA/Bd 421/18, Legalis nr 1864777.

Postanowienie Wojewódzkiego Sądu Administracyjnego w Gliwicach z dnia 13 kwietnia 2015 r., IV SA/G1 309/15, Legalis nr 1279745.

\section{LITERATURA}

Czebotar Łukasz, GąDzik Zuzanna, Łyżwa Aneta [i in.]: Komentarz. Ustawa o Policji, Warszawa: Wolters Kluwer S.A. 2015.

Doвкоwsкi Jarosław: Administracja bezpieczeństwa i porządku publicznego, [w:] Wybrane zagadnienia administracyjnego prawa materialnego, red. W. Bednarek, Olsztyn: Wydawnictwo Uniwersytetu Warmińsko-Mazurskiego 2000, s. 137-164.

DzıмıŃSKA-Mosio Monika: Ważny interes służby jako przesłanka zwolnienia funkcjonariusza Policji, [w:] Współczesne problemy prawa. Nadużycia prawa, Tom 2, red. I. Nowicka, D. Mocarska, Szczytno: Wydawnictwo Wyższej Szkoły Policji w Szczytnie 2016, s. 225-240.

GaceK Paweł: Nawiązanie stosunku służbowego z funkcjonariuszem Policji, Administracja Teoria Dydaktyka Praktyka 23 (2011), nr 2, s. 68-93.

Gacek Paweł: Odwołanie od rozkazu personalnego, Przeglad Policyjny 123 (2016), nr 3, s. 80-98.

GACeK Paweł: Opinia organizacji zakładowej związku zawodowego policjantów w sprawie zwolnienia ze służby w Policji (art. 43 ust. 3 ustawy o Policji), Policja. Kwartalnik Kadry Kierowniczej Policji 2 (2018), s. 26-37.

GACEK Paweł: Zmiana stadium postępowania karnego jako podstawa do zwolnienia policjanta ze służby w Policji ze względu na „ważny interes służby”, Przegląd Policyjny 128 (2017), nr 4, s. 70-99.

Hanausek Tadeusz: Ustawa o Policji. Komentarz, Kraków: Kantor Wydawniczy Zakamycze 1996.

KACPRZAK Jan: Stosunki służbowe w formacjach zmilitaryzowanych - charakter prawny, ochrona sądowa, Przegląd Policyjny 33 (1994), nr 1, s. 97-111.

Kотошsкi Wojciech: Ustawa o Policji. Komentarz, Warszawa: Wolters Kluwer Polska sp. z o.o. 2008. 
Leksykon policyjny, red. W. Pływaczewski, G. Kędzierska, Szczytno: Wydawnictwo Wyższej Szkoły Policji w Szczytnie 2001.

LeoŃsKi Zbigniew: Materialne prawo administracyjne, Warszawa: C.H. Beck 2000.

Liwo Marian: Status służb mundurowych i funkcjonariuszy w nich zatrudnionych, Warszawa: LexisNexis 2013.

Maciejko Wojciech, Korcz-Maciejko Aneta: Postępowanie w sprawach osobowych w Policji, Wrocław: GASKOR 2010.

Maciejko Wojciech, Rojewski Michał, SuŁawko-Karetko Agnieszka: Prawo administracyjne. Zarys wykładu części szczególnej, Warszawa: C.H. Beck 2011.

Maсı̇јко Wojciech: Osobowe prawo administracyjne, Warszawa: C.H. Beck 2008.

NowACKi Józef, ToBor Zygmunt: Wstęp do prawoznawstwa, Katowice: Naukowa Oficyna Wydawnicza 1997.

Opaliński Bartłomiej, Rogalski Maciej, Szustakiewicz Przemysław: Ustawa o Policji. Komentarz, Warszawa: 2015, Legalis/el.

Opaliński Bartłomiej, Szustakiewicz Przemysław: Policja studium administracyjnoprawne, Warszawa: Oficyna Wydawnicza Uczelnia Łazarskiego 2013.

PAŚniK Jerzy: Prawo dyscyplinarne w Polsce, Warszawa: Oficyna Prawnicza MUZA S.A. 2000.

Piątek Zbigniew, Socha Robert, Wars Piotr: Charakterystyka Policji, [w:] Współczesny wymiar funkcjonowania Policji, red. B. Wiśniewski, Z. Piątek, Warszawa: Akademia Obrony Narodowej 2009, s. 29-46.

PiePRZnY Stanisław: Policja. Organizacja i funkcjonowanie, Warszawa: Wolters Kluwer Polska sp. z o.o. 2011.

Prawo administracyjne materialne, red. Z. Duniewska, B. Jaworska-Dębska, M. Stahl, Warszawa: Wolters Kluwer S.A. 2014.

Prawo Policyjne. Komentarz, red. S. Sagan, Katowice: Biuro Wydawnictw Prawniczych „POLBOD” 1992.

Sierocka Iwona: Nagrody roczne funkcjonariuszy Policji, Monitor Prawa Pracy 3 (2012), s. 128-131.

Szankin Tomasz: Służba w Policji, [w:] Prawo policyjne, red. M. Czuryk, M. Karpiuk, J. Kostrubiec [i in.], Warszawa: Difin S.A. 2014, s. 195-210.

Szustakiewicz Przemysław: Istota stosunku służbowego, [w:] Wojciech Maciejko, Przemysław SzuSTAKIEwicz, Stosunek służbowy w formacjach mundurowych, Legalis/el. 2016.

Szustakiewicz Przemysław: Stosunki służbowe funkcjonariuszy służb mundurowych i żołnierzy zawodowych jako sprawa administracyjna, Warszawa: Difin S.A. 2012.

Ura Edward, Ura Elżbieta: Prawo administracyjne, Warszawa: Wydawnictwo Prawnicze LexisNexis 2004.

URA Elżbieta: Administracja bezpieczeństwa i porządku publicznego, [w:] Prawo administracyjne, red. E. Ura, Rzeszów: Wydawnictwo Oświatowe FOSZE 1997, s. 348-374.

WieCzOREK Mariusz: Charakter prawny stosunków służbowych funkcjonariuszy służb mundurowych, Torun: Wydawnictwo Adam Marszałek 2017.

ZIELIŃSKI Tadeusz: Stosunek prawa pracy do prawa administracyjnego, Warszawa: Państwowe Wydawnictwo Naukowe 1977.

ZoRSKA Maria: Komentarze do ustaw z 31 stycznia 1950 r. o stosunku służbowym funkcjonariuszów Milicji Obywatelskiej i z 31 stycznia 1959 r. o zaopatrzeniu emerytalnym funkcjonariuszów Milicji Obywatelskiej i ich rodzin, Warszawa: druk MSW 1960.

Żywucka-KozŁowska Elżbieta: Policja. Zagadnienia wybrane, Szczecin: Szczecińska Szkoła Wyższa Collegium Balticum 2014. 


\section{ZWOLNIENIE ZE SŁUŻBY W POLICJI NA PODSTAWIE ART. 41 UST. 2 PKT 5 USTAWY O POLICJI A PRAWO POLICJANTA DO NAGRODY ROCZNEJ}

\section{Streszczenie}

Artykuł został poświęcony problematyce związanej z konstrukcją prawną nagrody rocznej. Instytucja ta została uregulowana w art. 110 ustawy z dnia 6 kwietnia 1990 r. o Policji. Omówiono warunki formalne, których spełnienie uprawnia do nabycia tego prawa, a także wskazano podmioty uprawnione do przyznania nagrody rocznej. Skoncentrowano również uwagę na kwestii zwolnienia ze służby w Policji, w tym na podstawie art. 41 ust. 2 pkt 5 ustawy o Policji i wskazano, w jakich okolicznościach zwolniony policjant nabywa uprawnienia do nagrody rocznej.

Słowa klucze: Policja; policjant; stosunek służbowy; zwolnienie ze służby; nagroda roczna

\section{DISSMISION FROM THE SERVICE OF THE POLICE BASED ON THE ART. 41 (2) (5) ACT ON THE POLICE AND THE RIGHT OF A POLICE OFFICER TO AN ANNUAL REWARD}

\section{Sum mary}

The article is devoted to the issues related to the legal structure of the annual award. This institution is regulated in the Art. 110 of April 6, 1990 on the Police. Formal conditions which have to be fulfilled to entitle and acquire this right were discussed. There were also indicated entities entitled to the annual award. Attention was also focused on the issue related to the dissmision from the Police, in particular on the Art. 41 (2) (5) Act on the Police and there was indicated in which circumstances in these situations dismissed police officer acquires the right to annual reward.

Key words: Police; Police officer; service relationship; dismission from the service of the Police; annual reward 